\title{
Knowledge about osteoporosis prevention among women screened by bone densitometry
}

\author{
Mariola Janiszewska, Ewelina Firlej, Dorota Żołnierczuk-Kieliszek, Małgorzata Dziedzic
}

Department of Health Sciences, Chair of Public Health, Medical University of Lublin, Lublin, Poland

\begin{abstract}
Introduction: Osteoporosis is an illness characterized by the handicapped endurance of the bones, causing an increased risk of fracture.

Aimof the study was to establish the level of knowledge about osteoporosis prevention among women screened by bone densitometry and to answer the question whether the level of knowledge is dependent on socio-demographic factors.

Material and methods: The research was realized by means of a survey method, a poll technique in 2014. The study involved 292 women aged 51-83. The examined women were patients undergoing bone densitometry in the healthcare centres in Lublin. The osteoporosis knowledge test (OKT, revised 2011) by Phyllis Gendler was used as a research tool. Gathered material was subject to descriptive and statistical analysis. Tukey's test, $t$-Student test and variance analysis (ANOVA) were all applied. A statistical significance level was set at $\alpha=0.05$.

Results and conclusions: Respondents presented the basic exercise knowledge $(M=9.97)$ and low knowledge concerning risk factors, screening and treatment of osteoporosis $(M=7.87)$. The calcium knowledge remained on an average level $(M=14.03)$. Better educated women, city inhabitants as well as women having very good or good social and welfare conditions showed a significantly higher level of knowledge about osteoporosis prevention. Even women undergoing bone densitometry examination present insufficient knowledge about osteoporosis prevention.
\end{abstract}

Key words: osteoporosis, women, densitometry.

\section{Introduction}

The World Health Organization classified osteoporosis as the $10^{\text {th }}$ most important disease associated with the progress of civilization in the contemporary world $[1,2]$.

It is an illness, for which the incidence increases with age. Osteoporosis regards the entire population in different periods of life; however women in the postmenopausal age and the elderly (over 70 years old) appear to be the most exposed to its development. The risk of falling ill, concerning women is growing proportionally to the age and doubles every decade after 65 years of age. It is estimated that worldwide osteoporosis affects $200 \mathrm{~m}$ women, from whom about $20-25 \%$ will sustain an injury in the form of a bone fracture. Taking into consideration the fact of extending the life of a statistical American or European woman, one should notice that the postmenopausal period easing fractures because of grater bone loss lasts for over 30 years in women's life [3].

In Europe, $1 / 3$ of all individuals diagnosed with osteoporosis are women in the postmenopausal period. In Poland, the number of people affected by osteoporosis amounts to over $6 \mathrm{~m}$, it constitutes $1 / 5$ of the population aged over $45.30-40 \%$ of postmenopausal women struggle with osteoporosis.

Osteoporosis is determined as "the quiet thief of the bone", what is associated with its asymptomatic course. This process is extremely complex, often takes place in the course of many years. Even when it comes to the violent and dynamic resorption within the bone, this will not trigger a feeling of pain, especially in early stages of this process. In consequence, a patient experiences a fracture that happens while performing everyday home activities as the effect of progressed damage to the bone tissue [4]. In the course of osteoporosis, the so-called low-energy fracture or fragility fracture is essential, that is the fracture caused by a minor trauma, for instance fall from the height of the body or hitting a table with a hand [5].

Fracture is the major clinical outcome of osteoporosis $[6,7]$. Osteoporosis is responsible for fragility fractures, which are associated with decreased physical and social functions [8]. Because of high costs of their treatment, osteoporotic fractures constitute a serious 
problem, both for the public health and health care system. The consequences of osteoporotic fractures encompass an increased percentage of disabled people in an ageing society. Poland is ranked among countries of greater risk of mortality as a result of such fractures. In 2010, these fractures were responsible for 43000 deaths, including $50 \%$ of deaths caused by the hip fracture in women. Most deaths took place within 3-6 months after the hip fracture [9].

On account of the long asymptomatic progression of the disease, a real and effective diagnostic test is needed [10]. At present the bone densitometry is considered to be "the golden standard" in the diagnostics of osteoporosis. It is ranked among non-invasive diagnostic methods. Moreover, high sensitivity and reliability of performed measures are the great advantages of the bone densitometry, which is crucial both for the evaluation of the progress of treatment and for forecasting future fractures.

The possibility of the measurement applies not only to persons with the diagnosed osteoporotic fracture but also those at the increased risk of the fracture. This type of the examination also allows for calculating the surface density of the expressed bone tissue measured by $\mathrm{BMC} / \mathrm{cm}^{2}$. The obtained repetitiveness of results supports the diagnostic testing of the analysed area of bones. The control of the effects of treatment reduces the costs of further pharmacotherapy. It is extremely important to perform the examinations using the DXA method because a $10 \%$ fall in the bone density increases the chance of spine fracture twice and the chance of hip fracture three times [11].

The asymptomatic course of the disease, especially in its initial stages, makes following the rules of osteoporosis prevention very important.

At present it is attempted to implement preventive programs directed at the health education of the most endangered groups of population. Primary prevention of the osteoporosis is the first and most important one. These actions include following the rules of a balanced diet, supplementation of calcium and vitamin $D_{3}$, appropriate physical activity, preventing falls, applying the hormone replacement therapy, taking thyrocalcitonin or bisphosphates [12]. All these actions together with avoiding the overuse of alcohol and cigarettes support keeping appropriate bone mass [13]. The supplementation of calcium and vitamin D exerts a positive effect on a muscular tissue, builds up the mass and strength of muscles constituting the crucial factor of osteoporosis prevention $[14,15]$. The negative influence of medicines on the bone metabolism is universally known, therefore one should pay special attention to the type of medicines taken and the possible interactions among them. The examples can be thyrocalcitonin, oestrogens or bisphosphates. They strengthen the bone tissue, but at the same time they have harmful side effects.
Summing up, in order to effectively prevent osteoporosis one should systematically implement principles of prevention since the youngest years. The adherence to the principles of the prevention since youth is building foundations of the strong skeleton which slows down the pace of the bone mass loss in the senile period [16].

\section{Material and methods}

The research was realized by means of a survey method, a poll technique, between January 2014 and April 2014. The study involved 292 women aged 51-83. The purposive sampling was used. The examined women were patients undergoing dual-energy X-ray absorptiometry in the following healthcare centres in Lublin, a city in south-eastern Poland:

- Non Public Healthcare Centre REUMED,

- Institute of Rural Health,

- Cardinal Stefan Wyszyński Specialist Provincial Hospital.

The questionnaires were given to respondents by researchers in person before and after the respondents' X-ray absorptiometry examination. Women participating in the study were informed about voluntary and anonymous participation in the study, and that the results obtained were gathered for scientific purposes only.

Osteoporosis knowledge test (OKT, revised 2011) by Phyllis Gendler was used as a research tool. Responses in the OKT were scored as correct and incorrect. Individual score was determined by totalling correct answers. The total possible score for OKT was 32 points, for OKT Calcium was 26 points, for OKT Exercise 20 points. The total possible score for the subscale concerning the knowledge about risk factors, screening tests and the treatment of osteoporosis was 14. The OKT scale was adapted and has been used in many countries of the world. The Polish version of OKT was translated based on the process of forward translation (into Polish), back translation (into English) and comparison (between the original English version and the back translation version). The results of reliability estimation on the basis of internal consistency were satisfying in all subscales of OKT. The Polish version of OKT had a Cronbach's $\alpha$ 0.628-0.632. However the use of OKT scale is limited, because the scale is not used as a measure of treatment efficacy in clinical trials, but evaluates the women's knowledge about osteoporosis prevention.

An original questionnaire consisting of 42 questions was also used. The questions included in the original questionnaire concerned the women's sociodemographic data as well as their knowledge and health behaviours in the aspect of osteoporosis prevention. Gathered material was subject to descriptive and statistical analysis. Values of analysed measurable parameters were described as average value and standard deviation, whereas non-measurable values were de- 
scribed with the help of the cardinality and the percentage. Tukey's test, $t$-Student test and variance analysis (ANOVA) were all applied. A statistical significance level was set at $\alpha=0.05$. Computer software IBM SPSS Statistics 19 was applied.

\section{Characteristics of the studied group}

The study group was constituted by women at the age from 51 up to 83. Arithmetic mean of the examined women's age was 61.5 years, standard deviation -8.55 years. In the examined group married women prevailed (67.8\%), widows constituted $19.2 \%$ of the examined, young unmarried girls $-6.8 \%$ and divorced women $6.2 \%$. Majority of respondents (85.6\%) were city residents, while $14.4 \%$ of respondents came from villages. Over a half $(52.1 \%)$ of the respondents had secondary education, $27.7 \%$ - higher education, $11.3 \%$ - vocational secondary education and $8.9 \%$ - elementary education. As regards social conditions, $74.4 \%$ of the examined determined them as very good and good, however $24.0 \%$ as average. Scanty percentage of the examined complained about bad conditions (1.7\%). Over half of the examined (56.2\%) lived off the disability pension or retirement pension, $33.9 \%$ of women were employed. Own business activity was conducted by $6.2 \%$ of the examined, and $3.8 \%$ were unemployed women. Almost half of the examined (47.6\%) defined their self-assessment of the health state as not very good. $40.8 \%$ judged it as good, and $6.5 \%$ very good. The remaining $5.1 \%$ of respondents assessed their health state as bad. For a fuller picture, the examined group of respondents were asked how they understood the notion of osteoporosis. Almost all respondents (94.2\%) claimed that osteoporosis was the illness of the skeleton which is characterized by a handicapped endurance of the bone, which causes the fragility fractures. Studies were conducted in a group of women undergoing bone densitometry. Straight majority of respondents (91.8\%) knew that the bone densitometry was an imaging method of the bone mineral density. It showed the incorrect reply of the remaining $8.2 \%$ of respondents.

\section{Results}

The majority of the examined women correctly indicated risk factors for osteoporosis, i.e. a low calcium diet $(71.2 \%)$, menopause $(74.7 \%)$, older age $(81.8 \%)$ and eating disorders (79.5\%). Unfortunately an appropriate dose of calcium recommended for the adults was indicated only by $28.1 \%$ of women. The substantial part of the respondents knew that for the correct calcium absorption, vitamin D was essential (77.2\%), and $75.7 \%$ of the women correctly indicated the sunlight as the source of vitamin D. Respondents also correctly indicat- ed the best sources of calcium: yoghurt (85.6\%), cheeses $(84.6 \%)$, ice-cream (46.6\%) and sardines (45.5\%). Unfortunately only $44.5 \%$ and $48.3 \%$ of respondents indicated dipsomania and cigarette smoking, respectively, as osteoporosis risk factors.

The largest percentage of the examined (46.9\%) was in favour of the fact that exercising 3 times a week enabled formation of strong bones which, as everybody knows, is insufficient (the correct answer is 5 times a week). Only $24.7 \%$ of the examined had knowledge that in order to strengthen bones one should exercise 30 minutes per day, and during exercises, should breathe quickly (17.8\%). Only $33.6 \%$ of respondents knew that brisk walking is the best way to prevent osteoporosis, $55.1 \%$ of women indicated running, $6.8 \%$ - weightlifting, and $69.9 \%$ - aerobics. The above data are presented in Table I.

The analysis of the results shows that the examined had the basic knowledge about risk factors, screening and treatment of osteoporosis $(M=7.87)$, also the basic knowledge concerning the role of the physical activity in osteoporosis prevention $(M=9.97)$. However, the knowledge about issues associated with the diet rich in calcium remained on an average level $(M=14.03)$. These data are presented in Table II.

For scientific purposes and statistical analysis, the examined population was divided into professionally active individuals and not working women. The occupational activity did not diversify respondents indeed in terms of the level of knowledge about prevention of osteoporosis. Based on average values it is possible to conclude that professionally active women had a slightly greater level of knowledge about the role of physical activity, but knowledge of osteoporosis risk factors, screening and treatment remained in both groups on almost an identical level (Table III).

Statistical analysis from the $t$-Student test applied proved a statistical relation between the self-assessment of social and welfare conditions of the examined women and OKT subscale results. The level of knowledge about osteoporosis prevention raised along with improving of the women's social and welfare conditions (Table IV).

The analysis of the results showed that respondents with higher education $(M=14.91)$ were characterized indeed by a higher level of knowledge about nutrition than respondents with primary education $(M=12.65)$ and vocational one $(M=12.88)$. The better knowledge of women with higher education regards the principles of correct nutrition above all including consumption of calcium-rich products, adverse effects of the wrong diet on the bone metabolism, significance of the solar exposure, the role of vitamin $D$, the acquaintance of products rich in calcium and necessary mineral ingredients i.e. sardine or broccoli.

Also as to the knowledge about risk factors, the screening and methods of osteoporosis treatment, 
Tab. I. Responses to the Osteoporosis Knowledge Test of women screened by bone densitometry

\begin{tabular}{|c|c|}
\hline Question, the correct answer in italics & $\begin{array}{c}\text { Percentage } \\
\text { of correct } \\
\text { answers }\end{array}$ \\
\hline 1. Eating a diet low in dairy products, more likely to get osteoporosis & $71.2 \%$ \\
\hline 2. Being menopausal; more likely to get osteoporosis & $74.7 \%$ \\
\hline 3. Having a parent or grandparent who has osteoporosis; more likely to get osteoporosis & $57.5 \%$ \\
\hline 4. Being a white and Asian woman; more likely to get osteoporosis & $38.4 \%$ \\
\hline 5. Being an elderly man; more likely to get osteoporosis & $81.8 \%$ \\
\hline 6. Having ovaries surgically removed; more likely to get osteoporosis & $39.4 \%$ \\
\hline 7. Taking cortisone (steroids e. g. Prednisone) for a long time; more likely to get osteoporosis & $34.2 \%$ \\
\hline 8. Being overweight; less likely to get osteoporosis & $20.5 \%$ \\
\hline 9. Having an eating disorder; more likely to get osteoporosis & $79.5 \%$ \\
\hline 10. Consuming more than 2 alcoholic drinks per day; more likely to get osteoporosis & $44.5 \%$ \\
\hline 11. Smoking on a daily basis; more likely to get osteoporosis & $48.3 \%$ \\
\hline 12. How many days a week do you need to exercise at least to strengthen bones; 5 days a week & $24.7 \%$ \\
\hline 13. To make strong bones exercise must be hard enough to make breathing; much faster, but talking is possible & $17.8 \%$ \\
\hline $\begin{array}{l}\text { 14. Which of the following activities (swimming, walking briskly, stretching) is the best way to reduce a person's } \\
\text { chance of getting osteoporosis? walking briskly }\end{array}$ & $33.6 \%$ \\
\hline $\begin{array}{l}\text { 15. Which of the following activities (bicycling, yoga, lifting weights) is the best way to reduce a person's chance of } \\
\text { getting osteoporosis? lifting weights }\end{array}$ & $6.8 \%$ \\
\hline $\begin{array}{l}\text { 16. Which of the following activities (jogging or running, golfing using a golf cart, gardening) is the best way to reduce } \\
\text { a person's chance of getting osteoporosis? jogging and running }\end{array}$ & $55.1 \%$ \\
\hline $\begin{array}{l}\text { 17. Which of the following activities (bowling, doing laundry, aerobic dancing) is the best way to reduce a person's } \\
\text { chance of getting osteoporosis? aerobic dancing }\end{array}$ & $69.9 \%$ \\
\hline 18. Which of these is the best source of calcium (apples, cheeses, cucumbers)? cheeses & $84.6 \%$ \\
\hline 19. Which of these is the best source of calcium (peanut butter, turkey meat, canned sardines)? canned sardines & $45.5 \%$ \\
\hline 20. Which of these is the best source of calcium (chicken, broccoli, grapes)? broccoli & $36.3 \%$ \\
\hline 21. Which of these is the best source of calcium (yoghurt, strawberries, cabbage)? yoghurt & $85.6 \%$ \\
\hline 22. Which of these is the best source of calcium (ice-cream, grapefruit, radishes)? ice-cream & $46.6 \%$ \\
\hline 23. What is the recommended amount of calcium for an adult? $1000-1200 \mathrm{mg}$ daily & $37.7 \%$ \\
\hline 24. How much milk must an adult drink to meet the recommended calcium intake? 3 or more glasses daily & $16.1 \%$ \\
\hline 25. Which is the best reason for taking a calcium supplement? not getting enough calcium from diet & $51.8 \%$ \\
\hline 26. Which vitamin is required for the absorption of calcium? vitamin $D$ & $77.2 \%$ \\
\hline 27. What is the best source of vitamin required for the absorption of calcium (carrot, orange, sunlight)? sunlight & $75.7 \%$ \\
\hline $\begin{array}{l}\text { 28. What is the best food source of the vitamin required for the absorption of calcium (spinach, cheese, salmon)? } \\
\text { salmon }\end{array}$ & $41.1 \%$ \\
\hline $\begin{array}{l}\text { 29. Which is the recommended amount of vitamin required for the absorption of calcium for an adult of } 50 \text { years old } \\
\text { and older? 800-1000 IU daily }\end{array}$ & $28.1 \%$ \\
\hline 30. When is the best time to build strong bones (childhood, adolescence, young adulthood)? adolescence & $33.2 \%$ \\
\hline 31. Osteoporosis can be diagnosed by (blood test, DXA scan, symptoms)? DXA scan & $82.9 \%$ \\
\hline 32. Once you have osteoporosis; you can take medication to treat it & $79.8 \%$ \\
\hline
\end{tabular}


Tab. II. The respondents' knowledge on osteoporosis: summing up

\begin{tabular}{|c|c|c|c|c|c|}
\hline Test of knowledge on osteoporosis & $N$ & $\begin{array}{l}\text { Minimum } \\
\text { score }\end{array}$ & $\begin{array}{l}\text { Maximum } \\
\text { score }\end{array}$ & $\begin{array}{l}\text { Average } \\
\text { score }\end{array}$ & $\begin{array}{l}\text { Standard devia- } \\
\quad \text { tion (SD) }\end{array}$ \\
\hline Calcium knowledge (total possible score 26 points) & 292 & 0 & 24 & 14.03 & 3.52 \\
\hline Exercise knowledge (total possible score 20 points) & 292 & 0 & 17 & 9.97 & 3.05 \\
\hline $\begin{array}{l}\text { Knowledge about risk factors, screen tests and treat- } \\
\text { ment (total possible score } 14 \text { points) }\end{array}$ & 292 & 0 & 14 & 7.87 & 2.41 \\
\hline
\end{tabular}

Tab. III. The level of knowledge on osteoporosis according to respondents' employment status

\begin{tabular}{|c|c|c|c|c|c|c|c|c|}
\hline & \multicolumn{6}{|c|}{ Employment status } & \multirow{2}{*}{\multicolumn{2}{|c|}{$t$-Student test }} \\
\hline & \multicolumn{3}{|c|}{ Employees } & \multicolumn{3}{|c|}{ Non-employees } & & \\
\hline & $N$ & M & SD & $N$ & M & SD & $t$ & $P$ \\
\hline Calcium knowledge & 205 & 14.14 & 3.641 & 87 & 13.77 & 3.216 & 0.814 & 0.417 \\
\hline Exercise knowledge & 205 & 10.10 & 3.053 & 87 & 9.68 & 3.037 & 1.075 & 0.283 \\
\hline Knowledge about risk factors, screen tests and treatment & 205 & 7.95 & 2.445 & 87 & 7.68 & 2.325 & 0.855 & 0.377 \\
\hline
\end{tabular}

Tab. IV. The level of knowledge on osteoporosis according to respondents' self-assessment of living conditions

\begin{tabular}{|c|c|c|c|c|c|c|c|}
\hline & & \multirow{2}{*}{$N$} & \multirow{2}{*}{$M$} & \multirow{2}{*}{ SD } & \multicolumn{2}{|c|}{ ANOVA } & \multirow{2}{*}{$\begin{array}{c}\text { Tukey's } \\
\text { test }\end{array}$} \\
\hline & & & & & $\mathrm{F}$ & $p$ & \\
\hline \multirow{4}{*}{ Calcium knowledge } & very good (1) & 46 & 15.13 & 3.79 & \multirow{4}{*}{3.424} & \multirow{4}{*}{0.018} & \multirow{4}{*}{$1-3$} \\
\hline & good (2) & 171 & 14.14 & 3.26 & & & \\
\hline & average (3) & 70 & 13.11 & 3.77 & & & \\
\hline & poor (4) & 5 & 12.80 & 3.11 & & & \\
\hline \multirow{4}{*}{ Exercise knowledge } & very good (1) & 46 & 10.87 & 3.26 & \multirow{4}{*}{2.953} & \multirow{4}{*}{0.033} & \multirow{4}{*}{$1-3$} \\
\hline & $\operatorname{good}(2)$ & 171 & 10.06 & 2.83 & & & \\
\hline & average (3) & 70 & 9.20 & 3.30 & & & \\
\hline & poor (4) & 5 & 9.60 & 3.13 & & & \\
\hline \multirow{7}{*}{$\begin{array}{l}\text { Knowledge about risk factors, } \\
\text { screen tests and treatment }\end{array}$} & very good (1) & 46 & 8.72 & 2.77 & \multirow{7}{*}{3.835} & \multirow{7}{*}{0.010} & \multirow{7}{*}{$1-3$} \\
\hline & $\operatorname{good}(2)$ & 171 & 7.92 & 2.19 & & & \\
\hline & average (3) & 70 & 7.20 & 2.54 & & & \\
\hline & poor (4) & 5 & 7.80 & 1.92 & & & \\
\hline & good (2) & 171 & 16.28 & 3.79 & & & \\
\hline & average (3) & 70 & 15.11 & 4.45 & & & \\
\hline & poor (4) & 5 & 14.60 & 4.16 & & & \\
\hline
\end{tabular}

women with higher education had greater knowledge $(M=8.35)$ as compared to women with vocational education ( $M=7.15)$. These differences point to a higher level of health awareness in better educated individuals. A greater store of knowledge can determine prohealth behaviours influencing the elimination of risk factors (Table V).

The women's self-assessed state of health did not affect their level of knowledge concerning osteoporosis.
Conducted statistical analysis applying the ANOVA variation and the Tukey's test showed no essential statistical relations within individual groups.

\section{Discussion}

Our study showed that the level of knowledge about osteoporosis prevention in the examined women remained insufficient and was dependent on the wom- 
Tab. V. The knowledge on osteoporosis according to women's education level

\begin{tabular}{|c|c|c|c|c|c|c|c|}
\hline & & \multirow{2}{*}{$N$} & \multirow{2}{*}{$M$} & \multirow{2}{*}{ SD } & \multicolumn{2}{|c|}{ ANOVA } & \multirow{2}{*}{$\begin{array}{l}\text { Tukey's } \\
\text { test }\end{array}$} \\
\hline & & & & & $\mathrm{F}$ & $p$ & \\
\hline \multirow{4}{*}{ Calcium knowledge } & higher (1) & 81 & 14.91 & 3.564 & \multirow{4}{*}{4.353} & \multirow{4}{*}{0.005} & \multirow{4}{*}{$\begin{array}{l}1-3 \\
1-4\end{array}$} \\
\hline & secondary (2) & 152 & 14.04 & 3.375 & & & \\
\hline & primary (3) & 26 & 12.65 & 2.607 & & & \\
\hline & vocational (4) & 33 & 12.88 & 4.106 & & & \\
\hline \multirow{4}{*}{ Exercise knowledge } & higher (1) & 81 & 10.52 & 2.886 & \multirow{4}{*}{2.636} & \multirow{4}{*}{0.050} & \\
\hline & secondary (2) & 152 & 10.00 & 3.012 & & & \\
\hline & primary (3) & 26 & 9.58 & 2.469 & & & \\
\hline & vocational (4) & 33 & 8.82 & 3.729 & & & \\
\hline \multirow{4}{*}{$\begin{array}{l}\text { Knowledge about risk factors, screen } \\
\text { tests and treatment }\end{array}$} & higher (1) & 81 & 8.35 & 2.346 & \multirow{4}{*}{2.948} & \multirow{4}{*}{0.033} & \multirow{4}{*}{$1-4$} \\
\hline & secondary (2) & 152 & 7.90 & 2.397 & & & \\
\hline & primary (3) & 26 & 7.12 & 1.840 & & & \\
\hline & vocational (4) & 33 & 7.15 & 2.774 & & & \\
\hline
\end{tabular}

en's education and social-economic status. Straight majority of women having secondary or higher education and better social conditions was characterized by the highest level of the calcium knowledge. These correlations are confirmed by other researches [13, 17].

Analysis of own studies did not show significant differences concerning awareness of the prevention of osteoporosis according to the women's employment status. It contradicts the results obtained by Kopiczko et al. [18] who examined Polish women over 48 years of age. Analysis of her original questionnaire results showed that $96.2 \%$ of respondents correctly characterised osteoporosis. Most popular methods of prophylaxis were proper consumption of animal protein, calcium, vitamin $D$, the exposure to the sunlight and proper exercises. The media i.e. radio, television and the Internet (25\%) were the main sources of knowledge of the examined about osteoporosis.

Ochota and Mroczek [19] presented similar conclusions, analysing knowledge about prevention of osteoporosis in women over 40 years of age and students of physiotherapy. Over a half of respondents correctly defined the term osteoporosis and assigned the bone structure as closely connected with the illness. A bit different results were obtained by Podbielska et al. [20] in a group of women over 50 years of age. It turned out that only $21 \%$ of them applied principles of osteoporosis prevention through the bone densitometry examinations or proper exercises (49\%). Comparable results were obtained as to sources of information about this disease, where media (radio, television) proved to be the dominant source of knowledge indicated by $63.7 \%$ of patients [20]. Gowin et al. [22] wanting to emphasize how crucial physical activity is proved that the training of the balance lowered the risk of osteoporotic fractures especially amongst women with diagnosed osteoporosis. As it turned out, the straight majority of respondents started to do proper exercises as late as after being diagnosed with osteoporosis. It proves the shortage of knowledge about osteoporosis prevention and the need of further education in this respect.

Results of a statistical analysis in own studies showed that the domicile and social and welfare conditions were an essential variable with reference to the level of knowledge about osteoporosis. Respondents living in cities had the highest level of knowledge about osteoporosis. Silva et al. [23] got similar results from conducted studies in a group of 232 women in the postmenopausal period with diagnosed osteoporosis or osteopenia.

Our own studies show that the education affected the level of knowledge about osteoporosis. Women with higher education had a better knowledge than women with primary or vocational education. A little bit different results were obtained by Chen et al. [24]. They studied the level of knowledge about osteoporosis and risk factors for this illness amongst nurses, experts in public health working in Taiwan. It turned out that respondents which did not obtain a university degree, but finished the lifelong education, which included a subject of osteoporosis, had the highest level of knowledge of osteoporosis.

The menopause is one of determining risk factors for osteoporosis, followed by processes of the bone resorption. Its consequences reduce bone mass and increase the risk of fractures [16]. A hormone replacement therapy taken on can mitigate the risk of osteoporosis [25].

The relation between the education and possessed knowledge was noticed by Ho et al. [26]. In their view, the level of education is an operand towards BMD and the prevalence of osteoporosis after the menopause amongst respondents from China.

Analysis of own data showed the lack of correlations between self-assessment of the health, and possessed knowledge. Different results were obtained by 
Skrzypczak and Szczepańska [27] who proved that the threat of osteoporosis depended first of all on the state of health. In the available literature, also Dytfeld et al. [28] divided the examined group into two groups: respondents with the fracture and without the fracture.

Pro-health behaviours i.e. relevant diet, physical activity or avoiding substance overuse are all strengthening the state of our health. This seems to be portrayed by Mędrela-Kuder and Bis[29] who proved that women with osteopenia made dietary mistakes more often, i.e. consumed too few products rich in calcium and vitamin $D$ in childhood as well as at the moment of conducting the survey, more often drank coffee than the control group. And so health education about the risk factors for osteoporosis and principles of the disease prevention is necessary. Goluch-Koniuszy et al. [30] in their studies divided the studied group into two subgroups: healthy women and women with diagnosed osteoporosis. In both subgroups, low consumption of calcium was observed i.e. in the form of milk and its products. Researchers mentioned above declare that the reasons of this behaviour are to be found in the basic level of the examined women's knowledge. They emphasize the need for education since one's childhood. Numerous studies show that the amount of consumed calcium in the form of milk products, in spite of the growing awareness, is still too small. Similar conclusions were drawn by Oudshoorna et al. [31] who explored the level of knowledge about calcium and vitamin D.

\section{Limitations}

There may have been participant recall bias which would be a systematic error resulting from lack of completeness of memory of past events or experiences, which may have affected accuracy of self-reported information.

\section{Conclusions}

1. Women undergoing bone densitometry presented the basic exercise knowledge $(M=9.97)$ and low knowledge concerning risk factors, screening and treatment of osteoporosis $(M=7.87)$. The calcium knowledge remained on an average level $(M=$ 14.03).

2. The level of education diversified the level of knowledge of examined women indeed statistically in individual OKT subscales. Respondents with higher education had a greater store of knowledge in nutrition, physical activity, risk factors, screening and methods of treatment of osteoporosis as opposed to women with primary education or vocational education.

3. City inhabitants as well as women having very good or good social and welfare conditions showed a sig- nificantly higher level of knowledge about the osteoporosis prevention.

4. Statistical analysis did not show substantial differences between the women's professional status or self-assessment of the health and osteoporosis prevention knowledge.

\section{Disclosure}

Authors report no conflict of interest.

\section{References}

1. Tryniszewski W, Sobczuk A, Górska-Chrząstek M, et al. Ocena wskaźnika metabolizmu kostnego oraz wyznaczenie zakresu jego wartości prawidłowych u zdrowych kobiet i mężczyzn. Prz Menopauz 2011; 1: 51-53.

2. Kanis J, McCloskey EV, Johansson $\mathrm{H}$, et al. European guidance for the diagnosis and management of osteoporosis in postmenopausal women. Osteopor Int 2012; 24: 23-57.

3. Sewerynek E, Horst-Sikorska W, Stępień-Kłos W. The role of counselling and other factors in compliance of postmenopausal osteoporotic patients to alendronate 70 therapy. Arch Med Sci 2013; 9: 288-296.

4. Wawrzyniak A. Osteoporoza wyzwaniem dla lekarzy rodzinnych. Lek Rodz 2013; 10: 696-698.

5. Matusik H, Lorenc R, Walecki J. Densytometria kości-podstawy, metoda badań oraz interpretacja wyników. In: Diagnostyka osteoporozy. Lorenc R (ed.). Springer PWN, Warszawa 1998; 12-14.

6. Shen $\mathrm{H}$, Xie J, Lu H. Vitamin D receptor gene and risk of fracture in postmenopausal women: a meta-analysis. Climacteric 2014; 17: 319-324.

7. Lorenc R, Głuszko P, Karczmarewicz E. Zalecenia postępowania diagnostycznego i leczniczego w osteoporozie. Aktualizacja 2013. Med Prakt Wyd Spec 2013; 1: 1-44.

8. Palacios S, Neyro JL, Fernández de Cabo S, et al. Impact of osteoporosis and bone fracture on health-related quality of life in postmenopausal women. Climacteric 2014; 17: 60-70.

9. Głuszko P, Karczmarewicz E, Lorenc R. Osteoporoza - postępy 2012. Med Prakt 2013; 6: 29-34.

10. Malabanan AO, Rosen HN, Vokes TJ, et al. Indications of DXA in Women Younger Than $65 \mathrm{yr}$ and Men Younger Than $70 \mathrm{yr}$ : The 2013 Official Positions. J Clin Densitom 2013; 4: 166-168.

11. Bieniek A. Studium mineralogiczne zjawiska osteoporozy głowy kości udowej człowieka w nawiązaniu do rentgenowskich badań densytometrycznych. PZWN, Kraków 2012; 121-136.

12. Goncerz G. Polskie zalecenia postępowania diagnostycznego i leczniczego w osteoporozie-podsumowanie aktualizacji 2013. Med Prakt 2013; 6: 40-47.

13. Edmonds E, Turner LW, Usdan SL. Osteoporosis knowledge, beliefs and calcium intake of college students: Utilization of the health belief model. Open J Prev Med 2012; 2: 27-31.

14. Czerwiński E, Borowy P, Kumorek A. Witamina D a układ mięśniowoszkieletowy. Stand Med 2012; 5: 651-652.

15. Zhao B, Zhang W, Du S, et al. Systematic review/Meta-analysis. Vitamin $D$ receptor Bsml polymorphism and osteoporosis risk in post-menopausal women. Arch Med Sci 2016; 12: 25-30.

16. Janiszewska M, Kulik T, Dziedzic M, et al. The contemporary look the problem of recognizing and diagnosing postmenopausal osteoporosis and eliminating the risk of a fall. Prz Menopauz 2014; 1: 2-6.

17. Ford MA, Bass M, Zhao Y, Bai JB, et al. Osteoporosis Knowledge. SelfEfficacy. and Beliefs among College Students in the USA and China. J Osteoporos 2011; 7: 2-6.

18. Kopiczko A. Aktywność fizyczna a gęstość mineralna kości u kobiet. Żyw Człow Metab 2012; 2: 124.

19. Ochota A, Mroczek M. Porównanie wiedzy kobiet po 40 roku życia i studentek fizjoterapii na temat osteoporozy. Zamojskie Studia i Materiały 2010; 35: 127-129. 
20. Podbielska M, Sokołowski K, Sokołowska M. Ocena poziomu wiedzy na temat osteoporozy i stosowanej profilaktyki wśród kobiet po 50 roku życia. Zesz Nauk WSSP 2013; 17: 88-95.

21. Szczygielska-Majewska M, Papis E. Styl życia a osteoporoza. Ann UMCS Sect D 2003; 58 suppl. 13: 242-245.

22. Gowin E, Horst-Sikorska W, Ignaszak-Szczepaniak M, et al. Czym straszy osteoporoza? Opinie pacjentek na temat wpływu osteoporozy na ich życie. Geriatria 2009; 3: 10-15.

23. Silva RB, Costa-Paiva L, Oshima MM, et al. Frequency of falls and association with stabilometric parameters of balance in postmenopausal women with and without osteoporosis. Rev Bras Ginecol Obstet 2009, 39: 496-502.

24. Chen IJ, Yu S, Wang TF, et al. Knowledge about osteoporosis and its related factors among public health nurses in Taiwan. Osteoporos Int 2005; 16: 2142-2148.

25. Lagari VS, Levis S. Phytoestrogens in the Prevention of Postmenopausal Bone Loss. J Clin Densitom : Assessment \& Management of Musculoskeletal Health 2012; 16: 445-446.

26. Ho SC, Chen Yu-ming, Woo JL. Educational Level and Osteoporosis Risk in Postmenopausal Chinese Women. Am J Epidem 2005; 161: 680-689.

27. Skrzypczak J, Szczepańska M. Hormonalna terapia zastępcza u kobiet po menopauzie. Służ Zdr 2005; 84: 33-34.

28. Dytfeld J, Marcinkowska M, Ignaszak-Szczepaniak M, et al. Porównanie przydatności kalkulatora Frax oraz Nguyena do oceny ryzyka złamań niskoenergetycznych oraz kwalifikacji do rozpoczęcia terapii u polskich kobiet z osteoporoza pomenopauzalną. Prz Menopauz 20; 6: 474-475.

29. Mędrela-Kuder E, Bis H. Porównanie odżywiania kobiet z prawidłową i obniżoną masą kostną. Bromatol Chem Toksyk 2011; 3: 418-420.

30. Goluch-Koniuszy Z, Radziszewska M, Dęga S. Ocena sposobu żywienia kobiet w okresie menopauzalnym - zdrowych i z leczoną osteoporozą. Folia Pomeranae 2010; 15: 7-15.

31. Oudshoorna Ch, Hartholta KA, Leeuwenb J, et al. Better knowledge on vitamin $\mathrm{D}$ and calcium in older people is associated with a higher serum vitamin D level and a higher daily dietary calcium intake. Health Educ J 2011; 71: 474-476. 